\section{Pediatric Review - International Journal of Pediatric Research}

\title{
Assessment of nutritional status of adolescent girls from 15-18 years in private high schools in Raipur, Chhattisgarh
}

\author{
Phuljhele S. ${ }^{1}$, Pandey P. ${ }^{2}$, Singh P. ${ }^{3 *}$ \\ DOI: https://doi.org/10.17511/ijpr.2021.i02.02
}

${ }^{1}$ Sharja Phuljhele, Professor and HOD, Department of Paediatrics, Pt. J.N.M. Medical College, Raipur, Chhattisgarh, India.

2 Prankur Pandey, Assistant Professor, Department of Paediatrics, Pt. J.N.M. Medical College, Raipur, Chhattisgarh, India.

3* Prerana Singh, Postgraduate student, Department of Paediatrics, Pt. J.N.M. Medical College, Raipur, Chhattisgarh, India.

Background: Adolescent period is a phase of human development comprising the change from childhood to adulthood. Nutritional requirements increase to a great extent during this period as compared to the previous years of growth. Adolescence may represent a window of opportunity to prepare nutritionally for healthy adult life. The present study was intended to assess the nutritional status of school-going adolescent girls. Materials and Methods: This one-year community-based, cross-sectional study was conducted in private high schools in an urban area of Raipur, Chhattisgarh among 480 adolescent girls of $15-18$ years. All the selected adolescent girls were personally interviewed with the help of a pre-designed and pre-tested questionnaire regarding age, type of family, dietary habits and socioeconomic status. A three-day recall method was used to assess nutrient intake. The nutrient intake was calculated using tables of nutritive value of Indian foods. Results: As per WHO nutritional measurement criteria, children were classified as per their anthropometric criteria as, $31.46 \%$ had moderate stunting and $4.38 \%$ were severely stunted. $2.71 \%$ had severe thinness, $27.92 \%$ were thin and $7.71 \%$ were overweight. The major morbidity among study subjects was, $19.6 \%$ had conjunctival pallor(anaemia), $8.75 \%$ had dental caries, $6.46 \%$ had Vitamin B complex deficiency, $4.8 \%$ had angular stomatitis and $0.84 \%$ had Vitamin $A$ deficiency. Conclusion: The present study recommends that efforts should be made to reduce the prevalence of malnutrition among adolescent girls. For this regular health check-ups should be done at schools with the help of school authorities and hospitals.

Keywords: Adolescent girls, Dietary habits, Malnutrition

Corresponding Author

Prerana Singh, Postgraduate student, Department of Paediatrics, Pt. J.N.M. Medical College, Raipur, Chhattisgarh, India.

Email: prn1891rims@gmail.com
How to Cite this Article

Phuljhele S, Pandey P, Singh P. Assessment of nutritional status of adolescent girls from 15-18 years in private high schools in Raipur, Chhattisgarh. Pediatric Rev Int J Pediatr Res. 2021;8(2):72-81. Available From https://pediatrics.medresearch.in/index.php/ijpr/arti cle/view/662
To Browse

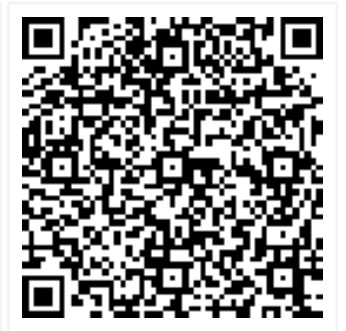

Manuscript Received 2021-03-15

Conflict of Interest No (c) 2021 by Sharja Phuljhele, Prankur Pandey, Prerana Singh and Published by Siddharth Health Research and Social Welfare
Society. This is an Open Access article licensed under a Creative Commons Attribution 4.0 International License https://creativecommons.org/licenses/by/4.0/ unported [CC BY 4.0].

Accepted 2021-04-07 2021-03-17

Funding

view Round 2 2021-03-18

Review Round 3

Note 


\section{Introduction}

The term adolescence has been derived from the Latin word "adolescere" which means "to grow up". World Health Organization (WHO) defines adolescents as individuals in the age group 10-19 years [1]. The adolescent period is often subdivided into early (10-13 years), middle (14-16 years) and late (17-19 years) adolescence [2]. There have been around 1.2 billion adolescents in the world, constituting $20 \%$ of the global population and 350 million adolescents constituting about 22\% of the population in countries of the South-East Asia Region (SEAR)[3]. There have been around 243 million adolescents in India, constituting $21 \%$ of the whole population in the country [4].

Adolescence is an important phase of growth and development. Unique changes occurring in an individual during adolescence are accompanied by progressive achievement of biological maturity. [5] This period is supposed to be very crucial since these are the formative years in the life of an individual when major physical, psychological and behavioural changes take place [6]. Adolescence may represent a window of opportunity to prepare nutritionally for healthy adult life [7]. During this period, adolescents gain up to $50 \%$ of their adult weight, $20 \%$ of their adult height and $50 \%$ of their adult skeletal mass. [8]

In India we face a big challenge regarding the nutritional status of adolescents with some studies showing that around half of them are wasted and $40 \%$ are stunted.[9] According to UNICEF, malnutrition in the form of anaemia is present in a large proportion of India's adolescents.[10] Chronically malnourished adolescents are more likely to remain undernourished during adulthood and pregnancy and thus are more likely to deliver low birth weight babies, thus creating a vicious cycle.[11]

Physical growth of adolescent girls has been related to their dietary behaviour and if this has been compromised, it may lead to malnutrition.[12] In India, the nutritional needs of adolescent girls, in particular, are often neglected.[13] Nutrition has been the cornerstone of socio-economic development and the problems related to nutrition are not just medical but multifactorial, with their roots in many other sectors of development such as education, demography, agriculture and rural development.[14]
In general, adolescent girls have been the worst sufferers of the ravages of various forms of malnutrition because of their increased nutritional needs and low social power.[15] Socio-cultural factors, the craze for trendy foods; peer influences, mood; body image; food habits of adolescents in the recent past and extreme changes in the lifestyle have affected both their nutrient intake and needs. [16]

Unfortunately assessment of the nutritional status of adolescent girls has been the least explored area of research particularly in India.[17] Since there was a need to conducted an insightful study to evaluate the nutritional status of school-going adolescent girls studying in class IX to XII in Raipur city, we selected school as our study places as the school going girls are easily accessible and also receptive.

\section{Material and Methods}

Study design: Community-based cross-sectional study.

Study duration: January 2019 to December 2019

Study setting: This study was conducted in selected private schools in the urban area of Raipur city.

Study population: A total of 480 adolescent girls attending high school and higher secondary school ranging from 15-18 years (IX-XII Standard) in Raipur city were studied.

\section{Inclusion criteria:}

- High school attending girls

- Age group 15-18 years

- Studying in Std IX-XII

\section{Exclusion criteria:}

- Age group $<15$ years and $>18$ years

- Girls studying in class other than IX-XII Std

- Girls with any genetic disease, metabolic problem or chronic disease.

- Girls with any history suggestive of any haemoglobinopathy or any dysmorphic features suggestive of genetic disease.

- Girls not giving consent

Methodology/ Data Collection: Girls were enrolled after taking proper consent from them and their school principal. 
Socio-demographic information was collected by using pre-tested and pre-designed structured proforma by interview technique. Nutritional status was assessed using anthropometry, clinical examination and general physical examination.

\section{Major variables:}

- Weight

- Height

- BMI- body mass index

\section{Outcome variables:}

- The proportion of adolescent girls classified as malnourished-both undernourished and overweight/obese

- The proportion of girls with moderate or severe stunting

- The proportion of clinically anemic girls.

- The proportion of adolescent girls with different vitamin deficiency.

\section{Confounding factors:}

01. Socio-economic status.

02. Religious belief.

03. Menstrual history.

04. Food habit.

\section{Statistical analysis}

- All relevant data were entered into pre-designed proforma and analyzed (with the help of a statistician) using Microsoft SPSS software for windows Version 20.0 and Microsoft Excel 2010.

- Data were expressed as a percentage and mean $+/-$ SD.

- The Chi-square test was used to analyze the significance of the difference between the distribution of data.

- P-value <0.05 was considered statistically significant.

\section{Results}

Out of the total of 480 adolescent girls in the study, the majority $(81.6 \%)$ were Hindu, $15.8 \%$ were Muslim, $54.38 \%$ girls had mothers who were educated up to Higher Secondary, $16.25 \%$ up to Middle School, whereas $9.58 \%$ girls had an illiterate mother. $58.13 \%$ of girls had fathers who were educated till Higher Secondary and $4.8 \%$ had an illiterate father.
The occupational status of fathers' of study subjects showed that $43.13 \%$ were doing jobs either informal or in-formal sector, $42.71 \%$ were involved in the small scale of self business, and $14.2 \%$ were daily wage workers. $81.1 \%$ of mothers of the study participants were housewife. $37.5 \%$ girls belonged to Upper Lower (Class IV) Class of Modified Kuppuswamy Scale, $34.79 \%$ belonged to Lower Middle (Class III) Class and $27.71 \%$ belonged to Upper Middle (Class II) Class. The majority of the study subjects were living in the nuclear family i.e. $73.95 \%$ whereas $26.05 \%$ were living in a joint family. $62.5 \%$ of the study subjects had fair environmental hygiene at home, $23.54 \%$ had good environmental hygiene and $13.96 \%$ had poor hygiene.

Table.1. Nutritional status as per WHO criteria for Height for Age

\begin{tabular}{|l|l|l|}
\hline \multicolumn{1}{|c|}{ Stunting } & Frequency & \multicolumn{1}{c|}{ Percentage } \\
\hline Severe (<-3SD) & 21 & 4.38 \\
\hline Moderate (<-2SD) & 151 & 31.46 \\
\hline Normal & 308 & 64.17 \\
\hline Total & 480 & 100 \\
\hline
\end{tabular}

Table.2. Nutritional status as per WHO criteriaBMI (Thinness)

\begin{tabular}{|l|l|l|}
\hline \multicolumn{1}{|c|}{ Particular } & \multicolumn{1}{c|}{ Frequency } & \multicolumn{1}{c|}{ Percent } \\
\hline Normal (-1 SD to +1 SD) & 296 & 61.67 \\
\hline Overweight $>$ +1SD & 37 & 7.71 \\
\hline Severe Thinness (<-3SD) & 13 & 2.71 \\
\hline Thinness (-3 SD to -1 SD) & 134 & 27.92 \\
\hline Total & 480 & 100 \\
\hline
\end{tabular}

Table.3. Distribution of Morbidity conditions in study subjects

\begin{tabular}{|l|l|l|}
\hline \multicolumn{1}{|c|}{ Disease } & Frequency & Percentage \\
\hline Anemia (Conjunctival Pallor) & 94 & 19.60 \\
\hline Dental Carries & 42 & 8.75 \\
\hline Vitamin B Complex deficiency & 31 & 6.04 \\
\hline Angular stomatitis (Lips) & 23 & 4.80 \\
\hline Vitamin A deficiency (Bitot's spot) & 4 & 0.84 \\
\hline
\end{tabular}

Table 4. Multivariate analysis for determinants of stunting in adolescent girls from 15 to 18 years old girls

\begin{tabular}{|c|c|c|c|c|c|}
\hline Variables & $\mid$ Stunting $(\%) \mid$ & Odds Ratio & P value & \multicolumn{2}{|c|}{ [95\% Conf. Interval] } \\
\hline \multicolumn{6}{|c|}{ Age in years } \\
\hline 15 year & 38.3 & \multicolumn{4}{|l|}{ Ref. } \\
\hline 16 year & 30 & 0.563 & 0.07 & 0.302 & 1.049 \\
\hline 17 year & 45 & 1.099 & 0.766 & 0.590 & 2.047 \\
\hline 18 year & 30 & 0.608 & 0.134 & 0.318 & 1.166 \\
\hline
\end{tabular}


Phuljhele S. et al: Assessment of nutritional status of adolescent

\begin{tabular}{|c|c|c|c|c|c|}
\hline \multirow{2}{*}{\begin{tabular}{|l} 
Hindu \\
Muslim
\end{tabular}} & \multirow{2}{*}{\begin{tabular}{|l|}
37 \\
28.9
\end{tabular}} & \multicolumn{4}{|l|}{ Ref. } \\
\hline & & 0.616 & 0.103 & 0.344 & 1.103 \\
\hline Christian & 41.7 & 0.907 & 0.882 & 0.249 & 3.299 \\
\hline \multicolumn{6}{|l|}{ Mother's education } \\
\hline Illiterate & 50 & \multicolumn{4}{|l|}{ Ref. } \\
\hline Primary & 27.6 & 0.388 & 0.099 & 0.126 & 1.194 \\
\hline Middle & 37.2 & 0.952 & 0.92 & 0.363 & 2.496 \\
\hline High school & 34.4 & 0.420 & 0.115 & 0.142 & 1.236 \\
\hline Higher Secondary & 36.4 & 0.497 & 0.061 & 0.240 & 1.032 \\
\hline Graduate & 17.6 & 0.190 & 0.004 & 0.061 & 0.594 \\
\hline \multicolumn{6}{|l|}{ Father's education } \\
\hline Illiterate & 3 & \multicolumn{4}{|l|}{ Ref. } \\
\hline Primary & 44.4 & 2.308 & 0.221 & 0.604 & 8.821 \\
\hline Middle & 40.7 & 2.646 & 0.205 & 0.587 & 11.930 \\
\hline High school & 26.8 & 0.623 & 0.513 & 0.151 & 2.572 \\
\hline Higher Secondary & 35.1 & 1.556 & 0.495 & 0.437 & 5.543 \\
\hline Graduate & 36.4 & 1.667 & 0.426 & 0.473 & 5.879 \\
\hline \multicolumn{6}{|l|}{ Father's occupation } \\
\hline Daily wages & 36.8 & \multicolumn{4}{|l|}{ Ref. } \\
\hline Job & 32.4 & 1.184 & 0.644 & 0.579 & 2.417 \\
\hline Self business & 39 & 1.358 & 0.39 & 0.676 & 2.729 \\
\hline \multicolumn{6}{|l|}{ Mother's occupation } \\
\hline Daily wages & 32 & \multicolumn{4}{|l|}{ Ref. } \\
\hline Job & 36.1 & 1.269 & 0.637 & 0.472 & 3.410 \\
\hline House wives & 36 & 1.424 & 0.327 & 0.702 & 2.891 \\
\hline Self business & 60 & 2.771 & 0.316 & 0.378 & 20.311 \\
\hline \multicolumn{6}{|l|}{ Type of family } \\
\hline Joint & 33.6 & \multicolumn{4}{|l|}{ Ref. } \\
\hline Nuclear & 36.6 & 0.952 & 0.857 & 0.557 & 1.627 \\
\hline \multicolumn{6}{|c|}{ Socio-economic status } \\
\hline SES-II & 26.3 & \multicolumn{4}{|l|}{ Ref. } \\
\hline SES-III & 38.3 & 1.646 & 0.113 & 0.889 & 3.050 \\
\hline SES-IV & 40.6 & 2.011 & 0.023 & 1.100 & 3.675 \\
\hline \multicolumn{6}{|c|}{ Environmental hygiene } \\
\hline Good & 38.1 & \multicolumn{4}{|l|}{ Ref. } \\
\hline Fair & 34.3 & 0.883 & 0.615 & 0.544 & 1.434 \\
\hline Poor & 38.8 & 0.896 & 0.768 & 0.431 & 1.863 \\
\hline \multicolumn{6}{|c|}{ Immunization status } \\
\hline Complete & 36 & \multicolumn{4}{|l|}{ Ref. } \\
\hline Incomplete & 35 & 1.058 & 0.847 & 0.596 & 1.878 \\
\hline \multicolumn{6}{|l|}{ Menstrual history } \\
\hline Regular & 37.1 & \multicolumn{4}{|l|}{ Ref. } \\
\hline Irregular & 33.3 & 0.880 & 0.65 & 0.507 & 1.528 \\
\hline No Menarche & 18.8 & 0.378 & 0.166 & 0.095 & 1.499 \\
\hline Teeth & & & & & \\
\hline Caries & 33.3 & Ref. & & & \\
\hline Normal & 36.1 & 1.071 & 0.852 & 0.524 & 2.188 \\
\hline Diet & & & & & \\
\hline Vegetarian & 35.7 & Ref. & & & \\
\hline Non vegetarian & 36 & 0.944 & 0.779 & 0.634 & 1.408 \\
\hline
\end{tabular}

\begin{tabular}{|l|l|l|l|l|l|}
\hline Regular & 35.6 & \multicolumn{4}{|l|}{ Ref. } \\
\hline Irregular & 36.5 & 1.012 & 0.957 & 0.654 & 1.567 \\
\hline
\end{tabular}

Height for age <-3SD as per NCHS/WHO standard 2007 was used as severe stunting in the present study. The mean height of the total 480 study subjects was $153.82 \pm 7.95 \mathrm{~cm}$. The prevalence of stunting was $35.8 \%$. The association of religion with stunting was not statistically significant $(p>0.05)$. The association of mother's education with stunting was statistically significant $(p=0.00)$ with the result showing that $26.1 \%$ of severely stunted girls belonging to illiterate mother whereas the association between father's occupation and stunting was not statistically significant.

The association between socioeconomic status and stunting was statistically significant $(p=0.001)$ with families belonging to SES-IV having a maximum of $8.9 \%$ severely stunted girls whereas families with SES-III having 3.3\% severely stunted girls. Protein deficit in the diet of study subjects was found to be statistically significant in association with stunting $(p=0.00)$ with $16 \%$ of girls with severe stunting having $>10 \mathrm{gm}$ protein deficit.

Mothers who were graduate had less chance of having their girl children stunted (OR-0.190, $\mathrm{P}=0.004$ ) as compared to illiterate mothers. Fathers who were educated had less chance of having their girl children stunted as compared to illiterate fathers. Fathers who do the job had more chance of having their girls stunted as compared to daily wagers. Mothers who were housewives had 1.424 times more chance (OR-1.424 $p=0.327$ ) of having their girl stunted as compared to daily wagers. Type of family did not have a significant impact on the stunting status of the girl child.

Girl child with SES-III status had more chance of having girl child stunted (OR-2.01, $\mathrm{P}=0.023$ ) as compared to lower SES status. Environmental hygiene, menstrual history, immunization status and dental caries did not have a significant impact on the stunting status of adolescent girls. Being vegetarian or non-vegetarian did not have a significant impact on the height of adolescent girls. Adolescent girls who were having irregular diet had little more chance of being stunted (OR-1.012, $\mathrm{P}=0.654$ ).

Table 5. Multivariate analysis for determinants of thinness in adolescent girls from 15 to 18 years old girls 
Phuljhele S. et al: Assessment of nutritional status of adolescent

\begin{tabular}{|c|c|c|c|c|c|}
\hline Thinness & $\begin{array}{c}\text { Thinness } \\
(\%)\end{array}$ & $\begin{array}{l}\text { Odds } \\
\text { Ratio }\end{array}$ & $\begin{array}{c}\text { P } \\
\text { value }\end{array}$ & \multicolumn{2}{|c|}{$\begin{array}{c}\text { [95\% Conf. } \\
\text { Interval] }\end{array}$} \\
\hline \multicolumn{6}{|l|}{ Age in years } \\
\hline 15 year & 26.7 & Ref. & & & \\
\hline 16 year & 25 & 0.913 & 0.788 & 0.471 & 1.769 \\
\hline 17 year & 30.8 & 1.266 & 0.483 & 0.655 & 2.450 \\
\hline 18 year & 40 & 2.124 & 0.025 & 1.100 & 4.099 \\
\hline \multicolumn{6}{|l|}{ Religion } \\
\hline Hindu & 29.3 & Ref. & & & \\
\hline Muslim & 40.8 & 2.046 & 0.011 & 1.179 & 3.550 \\
\hline Christian & 8.3 & 0.259 & 0.209 & 0.031 & 2.129 \\
\hline \multicolumn{6}{|c|}{ Mother's education } \\
\hline Illiterate & 26.1 & Ref. & & & \\
\hline Primary & 31 & 1.186 & 0.769 & 0.380 & 3.695 \\
\hline Middle & 30.8 & 0.979 & 0.969 & 0.337 & 2.846 \\
\hline High school & 25 & 1.044 & 0.942 & 0.324 & 3.369 \\
\hline $\begin{array}{l}\text { Higher } \\
\text { Secondary }\end{array}$ & 31.4 & 1.135 & 0.757 & 0.509 & 2.529 \\
\hline Graduate & 35.3 & 1.497 & 0.452 & 0.523 & 4.282 \\
\hline \multicolumn{6}{|c|}{ Father's education } \\
\hline Illiterate & 17.6 & Ref. & & & \\
\hline Primary & 29.6 & 2.287 & 0.303 & 0.474 & 11.046 \\
\hline Middle & 22.2 & 1.966 & 0.455 & 0.334 & 11.588 \\
\hline High school & 33.9 & 3.431 & 0.148 & 0.646 & 18.228 \\
\hline $\begin{array}{l}\text { Higher } \\
\text { Secondary }\end{array}$ & 31.2 & 2.470 & 0.242 & 0.543 & 11.240 \\
\hline Graduate & 32.2 & 2.720 & 0.193 & 0.602 & 12.282 \\
\hline \multicolumn{6}{|c|}{ Father's occupation } \\
\hline Daily wages & 30.9 & Ref. & & & \\
\hline Job & 28.5 & 0.627 & 0.229 & 0.293 & 1.340 \\
\hline Self business & 32.7 & 0.991 & 0.98 & 0.477 & 2.056 \\
\hline \multicolumn{6}{|c|}{ Mother's occupation } \\
\hline Daily wages & 28 & Ref. & & & \\
\hline Job & 16.7 & 0.675 & 0.504 & 0.213 & 2.141 \\
\hline House wives & 32.4 & 1.100 & 0.799 & 0.528 & 2.291 \\
\hline Self business & 20 & 1.096 & 0.939 & 0.104 & 11.540 \\
\hline \multicolumn{6}{|l|}{ Type of family } \\
\hline Joint & 29.6 & Ref. & & & \\
\hline Nuclear & 31 & 1.416 & 0.207 & 0.825 & 2.430 \\
\hline \multicolumn{6}{|c|}{ Socio-economic status } \\
\hline SES-II & 36.8 & Ref. & & & \\
\hline SES-III & 27.5 & 0.477 & 0.021 & 0.254 & 0.896 \\
\hline SES-IV & 2.9 & 0.708 & 0.272 & 0.382 & 1.311 \\
\hline \multicolumn{6}{|c|}{ Environmental hygiene } \\
\hline Good & 34.5 & Ref. & & & \\
\hline Fair & 30.3 & 0.752 & 0.261 & 0.458 & 1.236 \\
\hline Poor & 25.4 & 0.748 & 0.477 & 0.336 & 1.665 \\
\hline \multicolumn{6}{|c|}{ Immunization status } \\
\hline Complete & 31.2 & Ref. & & & \\
\hline Incomplete & 27.5 & 0.763 & 0.379 & 0.417 & 1.395 \\
\hline
\end{tabular}

\begin{tabular}{|l|l|l|l|l|l|}
\hline Regular & 29.7 & Ref. & & & \\
\hline Irregular & 33.3 & 1.109 & 0.718 & 0.633 & 1.944 \\
\hline No Menarche & 37.5 & 2.079 & 0.211 & 0.660 & 6.551 \\
\hline Teeth & 26.2 & Ref. & & & \\
\hline Carries & 31.1 & 1.387 & 0.393 & 0.655 & 2.939 \\
\hline Normal & 30.6 & Ref. & & & \\
\hline Diet & 30.6 & 1.022 & 0.919 & 0.676 & 1.543 \\
\hline Vegetarian & 30 & Ref. & & & \\
\hline Non vegetarian & 32.1 & 1.107 & 0.656 & 0.707 & 1.736 \\
\hline Pattern of diet & Regular &
\end{tabular}

BMI for age <-3SD of NCHS/WHO standard 2007 was used as severe thinness in the present study. The mean BMI of the total 480 study subjects was $19.75 \pm 3.26 \mathrm{~kg} / \mathrm{m} 2$. The overall prevalence of thinness in our study was $30.63 \%$.

As compared to Hindu girl children Muslim had 2.04 times (OR_2.04, $\mathrm{P}=0.011$ ) significantly more chance of being thin. Parent's education did not have a significant impact on the thinness status of adolescent girls. Mothers who were educated till graduation had 1.497 times more chance (OR1.497, $p=0.452$ ) of having their girl thin as compared to illiterate mother. Fathers who do the job and self business had less chance of having their girls thin as compared to daily wagers. Mothers who were doing the job had less chance (OR-0.675, $p=0.504$ ) of having their girl thin as compared to daily wagers. Type of family did not have a significant impact on the thinness status of the girl child. The socioeconomic status of a girl child did not have a significant impact on the thinness status of adolescent girls. Similarly environmental hygiene, menstrual history, immunization status, dental caries and diet did not have a significant impact on the thinness status of adolescent girls.

\section{Discussion}

In the present study, out of 480 school going adolescent girls an equal number of sample was taken from each age group. The age-wise maximum proportion of stunted girls against their sample maximum were (45\%) from 17 years age group followed by $38.33 \%$ from 15 years and lowest 30\% from 16 and 18 years age group. Rengma MS et al (2016) in Assam reported similar findings that a maximum of $47 \%$ of girls was stunted from 16 years age group followed by $38 \%$ from the 17 and 18 years age group and the lowest $33.5 \%$ from 15 years age group. [18] 
Similarly age-wise maximum proportion of thinness was $(40 \%)$ in 18 years age group, followed by (30.83\%) in 17 years and $26.67 \%$ in 15 years age group and the lowest $25 \%$ in 16 years age group. A similar study by Chandrashekarappa SM et al (2016) in Mysuru reported opposite findings that maximum $(35.3 \%)$ girls were thin from 16 years age group and lowest $18.3 \%$ from 18 years age group.[19]

Religion wise analysis of nutritional status showed that $29.33 \%$ were Hindu girls compared to $40.79 \%$ Muslim girls and it was statistically significant. Whereas $36.99 \%$ of Hindu girls were stunted as compared to $28.95 \%$ of Muslim girls and the association between stunting and religion was statistically not significant.

As compared to Hindu girl children Muslim girl children had a 2.04 times more chance of being thin (OR- 2.04, $P=0.011$ ). Rani $D$ et al (2018) in a similar study assessed the Nutritional Status of Teenage Adolescent Girls in the Urban Slum of Varanasi. They reported that $60.4 \%$ of Hindu girls were thin as compared to $57.1 \%$ of Muslim girls. Though like our study the association was statistically not significant. [20]

In the present study, $90.35 \%$ of mothers were educated and $9.65 \%$ were not educated. Of educated mothers $34.33 \%$ of girl children were stunted as compared to $50 \%$ of non-educated mothers. Whereas of educated mothers $31.11 \%$ girl children were thin as compared to $26.09 \%$ of noneducated mothers. This was statistically significant. In the present study, $96.46 \%$ of fathers were educated and $3.54 \%$ were not educated.

Fathers who were educated had $31.10 \%$ thin girls as compared to $17.65 \%$ of non-educated fathers. Whereas of educated fathers $35.85 \%$ girl children were stunted as compared to $35.29 \%$ of noneducated fathers. Fathers who were graduate had 1.497 times more chance (OR-1.479, $p=0.452$ ) of having their girl thin as compared to illiterate fathers.

A similar pattern in findings was observed in a study by Kunwar R and Pillai CB (2011) who did a study in primary schools of a large cantonment in New Delhi and reported that of illiterate fathers $36.51 \%$ of adolescent girls were undernourished and of educated father $30 \%$ were undernourished. Whereas of illiterate mothers $34.47 \%$ of adolescent girls were undernourished and of educated mother 29.7\% were undernourished.[21]
In the present study, daily wagers fathers had a high prevalence of $(30.88 \%)$ thinness as compared to those on jobs $(28.50 \%)$ and those doing self business had the highest prevalence of thinness $(32.68 \%)$ in their adolescent girls. Whereas daily wagers mothers had less prevalence of thinness $(28 \%)$ as compared to housewife mothers (32.39\%). Mothers who were doing jobs (16.67\%) and self business $(20 \%)$ had less prevalence of thinness as compared to daily wages and housewives. The Association between mother's occupation and nutritional status of their children was statistically significant. Fathers who do the job had less chance of having their girls thin (OR-0.627, $\mathrm{P}=0.229$ ) as compared to daily wagers. Mothers who do the job had half chance (OR-0.675, $p=0.504)$ of having their girl thin as compared to daily wages. Konwar P et al (2019) in the tea estates of Nazira subdivision of Sivasagar district, Assam reported that adolescent girls whose parents were unemployed had $60 \%$ stunting and thinness compared to those whose parents were employed had $50.38 \%$ of stunting and $50 \%$ thinness. [22]

In the present study, SES-II has more prevalence (36.84\%) of thinness in girls as compared to SESIII $(27.54 \%)$ and SES-IV (28.89\%). Whereas SESIV has maximum stunting ( $40.56 \%)$ as compared to SES-III (38.23\%) and SES-II (26.31\%). The Association between SES status and nutritional status of their children was statistically significant. Konwar P et al (2019) in the tea estates of Nazira subdivision of Sivasagar district, Assam found that adolescent girls belonging to the Upper middle class had $56.25 \%$ prevalence of stunting and $65.62 \%$ of thinness whereas the lower middle and lower class had $49.78 \%$ of stunting and $48.06 \%$ of thinness. [22]

In the present study, adolescent girls from the nuclear family had slightly more thinness $31 \%$ as compared to joint families $29.6 \%$. Whereas $34.51 \%$ of girls were thin in families where environmental hygiene was good, $30.33 \%$ in families where environmental hygiene was fair and $25.37 \%$ in families where environmental hygiene was poor. There was no statistically significant association between environmental hygiene and the nutritional status of adolescent girls. A similar study by Chandrashekarappa SM et al (2016) in JSS Medical College, Mysuru reported that $64 \%$ of adolescent girls from the nuclear family had thinness as compared to $36.5 \%$ of joint families and it was statistically not significant. [19] 
The immunization status of study subjects shows that, $31.25 \%$ of thin adolescent girls had their immunization status complete as compared to $27.5 \%$ of thin adolescent girls who had their immunization status incomplete. It was statistically not significant. The menstrual history of study subjects shows that $37.11 \%$ of adolescent girls were thin who had a regular menstrual history as compared to $33.33 \%$ of those who had irregular menstrual history. This association was statistically significant. Goyal R et al (2012) studied the Nutritional Status and Menarche in Adolescents of Punjab. They also had similar findings that $71.17 \%$ of adolescent girls were thin who had an irregular menstrual history as compared to $59.92 \%$ of those who had regular menstrual history. [23]

In the present study, $70.63 \%$ of adolescent had protein deficit and $70 \%$ had calorie deficit. 16\% severely thin girls had $>10 \mathrm{gm}$ of protein deficit and $5 \%$ severely thin girls had $5-10 \mathrm{gm}$ of protein deficit whereas $66 \%$ of thin girls had $>10 \mathrm{gm}$ of protein deficit. It has a statistically significant association. Similarly $36 \%$ severely thin girls and $60 \%$ of thin girls had $>400$ calorie deficit, whereas $37.7 \%$ of normal girls had a 200-400 calorie deficit. This also had a statistically significant association between calorie deficit and thinness in study subjects.

Konwar $P$ et al (2019) in Assam assessed the Nutritional status of adolescent girls belonging to the tea garden. They reported that calorie and protein deficits were found to be $76.60 \%$ and $65 \%$, respectively. [22]

In the present study $28.33 \%$ of the adolescent girls had irregular diet. Of those who had irregular diet $5.14 \%$ were severely thin girls and $27.21 \%$ were thin. It was a statistically not significant association b/w thinness and dietary intake. Whereas $53.57 \%$ of adolescent girls in the present study were vegetarian and $38 \%$ of them were severely thin and $55.22 \%$ of thin girls were vegetarian. There was no significant association $\mathrm{b} / \mathrm{w}$ thinness and type of diet. Kotecha, P. V. et al (2013) in Baroda studied the dietary pattern of school-going adolescent girls in urban areas. They reported that nearly $80 \%$ of adolescents were consuming regular food and nearly $60 \%$ of adolescents had their breakfast daily. [24] Shukla NK et al (2017) in Barabanki, Uttar Pradesh reported that about one-fourth of the girls stated that they never took breakfast before coming to school. Daily intake of breakfast was found in $16.9 \%$ of the study subjects while $43.0 \%$ of the girls stated about frequent missing of meals. [25]
In the present study the mean weight $(\mathrm{kg})$ of adolescent girls was $46.40 \pm 6.16$, mean height $(\mathrm{cm})$ was $153.82 \pm 7.95$ and mean BMI $(\mathrm{Kg} / \mathrm{M} 2)$ was 19.75 \pm 3.26 . Maximum thinness $40 \%$ (BMI <18.5) was in 18 year age group followed by $37.5 \%$ in 15 years, $38.8 \%$ in 16 year age group and $33.3 \%$ in 17 years age group. Choudhary $\mathrm{K}$ et al (2014) did a cross-sectional study in Govt. Sr. Sec. Girls' School in Bikaner, Rajasthan to assess the nutritional status of adolescent girls at a government senior secondary girls' school. Mean height \& Mean weight were $136.8 \mathrm{~cm} \& 28.64 \mathrm{~kg}$ respectively whereas the mean BMI was 15.244. [26] As per WHO criteria for Height for Age $(H / A)$, which measured the level of stunting in girls, $31.46 \%$ were in the moderate stunting category of malnutrition, and $4.38 \%$ of girls were severely stunted. As per WHO criteria for Body Mass Index (BMI), $2.71 \%$ of girls were in severe thinness, $27.92 \%$ were in Thinness and $7.71 \%$ were overweight. Banerjee, $S$ et al (2011) did the under-nutrition study among adolescents: a survey in five secondary schools in rural Goa. They found that $25.7 \%$ were thin and 7.7 were severely thin. [27] Baliga SS et al (2014) in a village in Peeranwadi district in Belgaum, Karnataka assessed the nutritional status of adolescents girls aged 15 to 19 years, $40.84 \%$ were stunted and $39.43 \%$ were thin. [28]

The major morbidity among study participants was $19.60 \%$ had conjunctival pallor (anemia), $8.75 \%$ had dental carries, $6.46 \%$ had Vitamin B complex deficiency, $6.04 \%$ pale nail, $34.80 \%$ had angular stomatitis in lips and $0.84 \%$ had Vitamin $A$ deficiency (Bitot's spot). Dambhare DG et al (2010) in High Schools of peri-urban areas in Wardha reported Morbidity among School going Adolescent girls. $38.89 \%$ had anaemia and $35.34 \%$ had dental caries. $13.79 \%$ had a refractory error, $7.76 \%$ had worm infestation. $6.9 \%$ had skin problems, $2.59 \%$ had tonsillitis and $2.59 \%$ had wax in the ear. [29] Susmitha KM et al (2012)in six social residential hostels of schedule cast girls in Nellore, Andhra Pradesh reported major morbid conditions among girls were Dental caries $28.04 \%$, Skin disorders 26.4\%.[30] Bhattacharya A et al (2015) did a study in three randomly selected co-educational schools of Burdwan District, West Bengal reported that about $55.18 \%$ had pallor, $40.33 \%$ had dental caries, $33.49 \%$ were suffering from refractive errors, $23.11 \%$ had a history of worm infestation, $38.90 \%$ had skin problems, and $68.61 \%$ adolescents had ENT problems.[31] 


\section{Conclusion}

The present study was conducted among high school girls from private schools in Raipur city of Chhattisgarh state to evaluate their nutritional status and morbidity pattern. More than one-third of the $(35.84 \%)$ late adolescent school girls were stunted, $30.63 \%$ were having some form of thinness and $19.60 \%$ had clinical anaemia.

The nutritional status of adolescent girls contributes to the nutritional status of the community. As a preventive strategy, there is a need to apply health and nutritional education program for inculcating healthy lifestyles. The present study recommends that efforts should be made to reduce the prevalence of malnutrition among adolescent girls. For this regular health check-ups should be done at schools with the help of school authorities and hospitals. All teachers and parents should be given health and nutritional education sessions by the health experts to enforce healthy eating habits among adolescent girl. Parents to be informed about the health status of the children by class teachers during parent-teacher meetings and appropriate measures should be taken to improve the lunch pack.

\section{What does this study add to existing knowledge?}

Effective implementation of this program should reach adolescents in their environment, such as in schools, families and communities. Skill-based nutrition education for the family and effective infection control and routine health assessment of school-going girls should be done.

\section{Author's contribution}

Dr. Sharja Phuljhele: Concept, study design

Dr. Prankur Pandey: Manuscript writing

Dr. Prerana Singh: Manuscript writing, Statistical analysis

\section{Reference}

01. World Health Organization. Strategic directions for improving adolescent health in South-East Asia Region. WHO Regional Office for South-East Asia. 2011.

Available from: [Article] [Crossref]
02. Sawyer SM, Afifi RA, Bearinger LH, Blakemore SJ, Dick B, Ezeh AC, Patton GC. Adolescence- a foundation for future health. Lancet. $2012 \mathrm{Apr}$ $28 ; 379(9826) 1630-40$.

doi: $10.1016 / S 0140-6736(12) 60072-5$ [Crossref]

03. Registrar General and Census Commissioner, India. Release of social and cultural tables - age data highlights. Ministry of Home Affairs. 2013. Available at _Age_data-final-12-09-2013 [Article] [Crossref]

04. Strategy Handbook. Rashtriya Kishor Swasthya Karyakram. Adolescent Health Division Ministry of Health and Family Welfare Government of India. January, 2014.

Available from: [Article] [Crossref]

05. Brabin L, Brabin BJ. The cost of successful adolescent growth and development in girls in relation to iron and vitamin A status. Am J Clin Nutr. 1992 May;55(5)955-8.

doi: 10.1093/ajcn/55.5.955 [Crossref]

06. Patil SN, Wasnik V, Wadke R. Health problems amongst adolescent girls in rural areas of Ratnagiri district of Maharashtra, India. J of Clinical and Diagnostic Research. 2009;Oct; 3; 1784-1790.

[Crossref]

07. Kaur TJ, Kochar GK, Agarwal T. Impact of nutrition education on nutrient adequacy of adolescent girls. Stud Home Comm Sci. 2007; 1;51-55.

[Crossref]

08. Akhter N, Sondhya FY. Nutritional status of adolescents in Bangladesh- Comparison of severe thinness status of a low-income family's adolescents between urban and rural Bangladesh. J Educ Health Promot. 2013 Jun $29 ; 2 ; 27$. doi: $10.4103 / 2277-9531.114209$ [Crossref]

09. Food and Nutrition Technical Assistance. India Nutrition Profile. Food and Nutrition Technical Assistance. 2014.

Available from: [Article] [Crossref]

10. UNICEF. India. Adolescents Nutrition. UNICEF India.

2018. Available from: [Article] [Crossref] 
11. World Health Organization. Adolescent NutritionA Review of the Situation in Selected South-East Asian Countries. Reg Off South-East Asia, New Delhi- World Health Organization. 2006;1-96. Available from: [Article] [Crossref]

12. Razzak A, Juliana FM, Hossain S, Asaduzzaman, Sadia U, Fatema-Tuj-Zohra. Socio-demography characteristics of parents of the adolescent girls in a nutrition education based intervention study in rural Bangladesh. J Nutr Health Food Eng. 2017;7(3)281-4.

[Crossref]

13. Basu A, Roy SK, Mukhopadhyay B, Bharati $P$, Gupta R, Majumdar PP. Sex bias in intrahousehold food distribution- roles of ethnicity and socioeconomic characteristics. Curr Anthropol. 1986;27;536-9.

[Crossref]

14. K Park. Park's Text Book of Preventive and Social Medicine, 22nd ed. Jabalpur- Banarasi das Bhanot Publication. 2013;p563.

[Crossref]

15. Choudhary S, Mishra CP, Shukla KP. Correlates of nutritional status of adolescent girls in the rural area of Varanasi. The Internet J of Nutr and Wellness. 2009;7(2).

[Crossref]

16. National Nutrition Monitoring Bureau. Diet and nutritional status of rural population, Hyderabad- National institute of Nutrition. Indian Council of Medical Research. 2002;p91. [Crossref]

17. HR Shivaramakrishna, AV Deepa, M Sarithareddy. Nutritional Status of Adolescent Girls in Rural Area of Kolar District - A CrossSectional Study. Al Ame en J Med Sci. 2011;4(3) 243-6. [Crossref]

18. Rengma MS, Bose K, Mondal N. Socio-economic and demographic correlates of stunting among adolescents of Assam, North-east India. Anthropol Rev. 2016;79(4)409-425.

[Crossref]

19. Chandrashekarappa SM, Ramakrishnaiah NMM, Manjunath R. Nutritional status in adolescent girls- Attempt to determine its prevalence and its association with sociodemographic variables. Family Medicine and Community Health. 2018;6(4)184-190.

doi: $10.15212 / \mathrm{FMCH} .2017 .0122$ [Crossref]
20. Divya Rani, Jitendra Kumar Singh, Mona Srivastava, Pragya Verma, Deepali Srivastava, S $P$ Singh. Assessment of Nutritional Status of Teenage Adolescent Girls in Urban Slum of Varanasi. International Journal of Current Research and Review Research. 2018;10(20)610.

DOI: 10.31782/IJCRR.2018.10202 [Crossref]

21. Kunwar $R$, Pillai $P$ B. Impact of education of parents on nutritional status of primary school children. Medical journal, Armed Forces India. 2002;58(1)38-43.

Doi: $10.1016 /$ S0377-1237(02)80011-9 [Crossref]

22. Konwar $P$, Vyas $N$, Hossain SS, Gore MN, Choudhury $M$. Nutritional status of adolescent girls belonging to the tea garden estates of Sivasagar district, Assam, India. Indian J Community Med. 2019;44;238-42.

[Crossref]

23. Goyal R, Mehta P and Kaur G. Nutritional Status and Menarche in Adolescents of Punjab. J Life Sci. 2012;4(1)63-66.

[Crossref]

24. Kotecha P V, Patel S V, Baxi R K, Mazumdar V S, Shobha M, Mehta K G, Mansi D, Ekta M. Dietary pattern of schoolgoing adolescents in urban Baroda, India. Journal of health, population, and nutrition. 2013;31(4)490-496.

Doi: $10.3329 /$ jhpn.v31i4.20047 [Crossref]

25. Nirpal Kaur Shukla, Mukesh Shukla, Siraj Ahmad, Ram Shukla. A Preliminary Study on Eating Habits among School Going Adolescent Girls in Barabanki District, Uttar Pradesh. Sch J App Med Sci. 2017;5(1C)184-187.

[Crossref]

26. Choudhary K, Shekhawat K, Kawatra A. A cross sectional study to assess nutritional status of adolescent girls at a government senior secondary girls' school at Bikaner, Rajasthan. Indian J Comm Health. 2014;26;Suppl S2;318321.

[Crossref]

27. KM Susmitha, Jyothi C, Prabakaran J. Morbidity pattern among the adolescent girls- A study in the social welfare hostels for scheduled castes, Nellore city, AP, India. Nat J Res Com Med. 2012;1(1)01-60.

[Crossref] 
28. Bhattacharya A, Basu M, Chatterjee S, Misra RN, Chowdhury G. Nutritional status and morbidity profile of school-going adolescents in a district of West Bengal. Muller J Med Sci Res. 2015;6;10-5.

[Crossref] 